\title{
Development of e-module combining science process skills and dynamics motion material to increasing critical thinking skills and improve student learning motivation senior high school
}

\author{
Fengky Adie Perdana ${ }^{1}$, Sarwanto $^{2}$, Sukarmin $^{3}$, Imam Sujadi $^{4}$ \\ ${ }^{1}$ Master of Science Sebelas Maret University, \\ ${ }^{2}$ Master of Physics Education Sebelas Maret University \\ ${ }^{3}$ Physics Education Department Sebelas Maret University \\ ${ }^{4}$ Mathematics Education Department Sebelas Maret University \\ J1. Ir. Sutami 36A Kentingan Jebres Surakarta 57126, INDONESIA \\ e-mail: fengkyadieperdana@gmail.com
}

\begin{abstract}
Learning media is one of the most components in the teaching and learning process. This research was conducted to design and develop the electronic modules combining science process skills and dynamics motion content for increasing critical thinking skills and improve student learning motivation for senior high school. The Methods used in this research is Research and Development (R\&D). Model research and development using a research 4D Thiagarajan model. Physics module was developed using science process skills approach: observing, formulating the problem, formulating a hypothesis, identify variables, conduct experiments, analyse the data, summarise and communicate. The results showed that: 1) the electronics module has been developed by integrating the science process skills for enhancing critical thinking skills and student motivation. 2) Electronic Module Physics-based science process skills meet the criteria very well, judging from the results of validation content, validation media, validation of peer education and practitioners, with an average value of 3.80 is greater than the minimum eligibility 3.78. 3) effectiveness the modules of science process skills got $\mathrm{N}$-gain value obtained from a large trial in grade samples of 0.67 and 0.59 in the control group were categorised as moderate. 4) Implementation of electronic modules Physics-based science process skills is considered an effective to enhance the students' motivation. Statistical analysis showed a significance value of 0.027 is lower than the significance level $\alpha=0.05$, this means that there are significant differences between learning motivation grade sample and the control class. As a result of analysis data obtained from the research, it was seen that the students' motivation that uses Physics module based science process skills better than conventional learning.
\end{abstract}

\section{Introduction}

Ministerial Regulation No.19 of 2005 on National Education Standards (NES) explained that the process of learning in the educational unit organized in an interactive, inspiring, fun, challenging, motivating the students to actively participate and provide enough space for innovation, creativity, and independence according with talents, interests, and physical and psychological development of learners. Therefore, the 
learning process should be designed, implemented teachers as educators can fulfil the mandate of the government regulations.

The media is all the physical tools that can present the message and stimulate students to learn. Examples are books, films, tapes, films frame. One of the media resources that students can use for independent study is in the form of modules. Modules are teaching media that can be used by students to learn independently with minimal assistance from others. [1]. The opinions affirm that the learning process takes a module to complement the student handbook, in which one of the characteristics of a medium of learning is motivation and curiosity of students. Development of learning modules intended for self-learning students, so that with the given module to assist in motivating students can learn and improve learning outcomes of the students themselves.

The electronics module is a form of presentation of material self-learning systematically arranged into units of learning smallest to achieve specific learning presented in the electronic format in which there is animation, audio, navigation makes the user more interactive with the program. [2]. Electronic media that can be accessed by students has benefits and different characteristics. If the terms of the benefits of electronic media alone can make the learning process more interesting, interactive, can be done anytime and anywhere and can improve the quality of learning.

"Critical thinking is that mode of thinking-about any subject, content, or problem in which the thinker improves the quality of his or her thinking by skillfully taking charge of the structures inherent in thinking and imposing intellectual standards upon them".[3]. Critical thinking is a widely-used term with a very ambiguous meaning. However, some researchers have thoroughly studied critical thinking and developed some useable definitions. [4]. While it would be too laborious to discuss the various definitionsThe three highest levels (analysis, synthesis, and evaluation) are frequently said to represent critical thinking. [5].

Pan et. al. (2010: 151) states that motivation is when the only reason for getting something out of the activity itself, such as passing the exam. [6].In this study developed learning modules that one of the characteristics of the module itself is to motivate student learning. Motivation posed by this learning module included in the extrinsic motivation. Extrinsic motivation is the motives for their active and functioning of the stimulus from the outside. [7]. The opinion was explained that the motivation that comes from outside the student is extrinsic motivation, so the motivation generated by the learning module is included extrinsic motivation. The motivation that comes from this module will generate curiosity and interest in increasing student learning. When the curiosity and interest of student learning increase the students' learning activities will also be proportional. Student activity will increase as motivated students with the use of modules developed, so that the study results will increase.

The motivation as the overall driving force within the students who lead learning activities, which ensures continuity of learning activities that give direction to the learning activities, so that the desired destination by a subject of study that can be achieved.[7]. Motivation is a change in yourself or a private person who is marked by 
the emergence of feelings and reactions to achieve the goal. Prior to the development process, the students were given a questionnaire of motivation as much as a 40-point declaration to measure students' motivation, as well as supporting data observations of the student motivation questionnaire filling. suggests that the characteristics of motivated people there are eight aspects. Results of preliminary observations students motivation are shown in Table 2 using a Likert scale can be seen that the initial conditions of students' motivation need to be improved. Proved that students still get bored of the routine tasks are undertaken, enjoy working independently, are less able to defend their opinions and less happy locate and troubleshoot problems.

\section{Numerical Methods}

Methods and study design using the design of Research and Development (R\&D) of Thiagarajan and Sammel with the steps: define, design, develop and disseminate. Broadly speaking, the data collection instruments in this study such as: questionnaires, sheets validation, test questions, and the observation sheet. [8]. The instrument is a tool or facility used by researchers to collect data in order to better results, in terms of more accurate, complete, and systematic so more easily processed. [9]. The steps undertaken in development research are described on table 1:

Table 1. Steps Undertaken in Development Research

\begin{tabular}{|c|c|c|}
\hline Steps & Work Log & Descriptions \\
\hline Define & $\begin{array}{l}\text { - Identify needs } \\
\text { - Identify contents } \\
\text { - Identify goals- } \\
\text { objectives } \\
\text { - Identify teaching } \\
\text { methods } \\
\text { - Identify evaluation } \\
\text { materials } \\
\text { - Identify instructional } \\
\text { media } \\
\text { - Analysis Curriculum }\end{array}$ & $\begin{array}{l}\text { - identified a problem in the enforceability } \\
\text { of physics learning activities in class X } \\
\text { SMA Warga Surakarta. } \\
\text { - Instruments used in this stage is a } \\
\text { questionnaire to know the needs of } \\
\text { students and teachers. The analysis used } \\
\text { is qualitative analysis based on the results } \\
\text { of questionnaires were obtained. }\end{array}$ \\
\hline Design & $\begin{array}{l}\text { - Create module design, } \\
\text { - Create cover, } \\
\text { introduction \&content } \\
\text { module, } \\
\text { - Design matrix-based } \\
\text { electronic module }\end{array}$ & $\begin{array}{l}\text { - Designed the electronic modules Physics- } \\
\text { based learning science process skills to } \\
\text { improve the ability of critical thinking } \\
\text { and student motivation. } \\
\text { - Designed matrix-based electronic module } \\
\text { that integrates science process skills with } \\
\text { aspects of critical thinking ability and } \\
\text { motivation to learn. }\end{array}$ \\
\hline Develop & $\begin{array}{l}\text { - produce modules, } \\
\text { - determine the level of } \\
\text { effectiveness in the }\end{array}$ & $\begin{array}{l}\text { - validation material\&modules by experts, } \\
\text { education professionals and peers } \\
\text { - Revise the comment given by experts, }\end{array}$ \\
\hline
\end{tabular}




\begin{tabular}{|c|c|c|}
\hline & $\begin{array}{l}\text { learning module, } \\
\text { - Applied module, } \\
\text { - determine the sheet of } \\
\text { affective, } \\
\text { psychomotor, process } \\
\text { skills science ability, } \\
\text { critical thinking } \\
\text { ability and the } \\
\text { student's motivation } \\
\text { - Post-test critical } \\
\text { thinking }\end{array}$ & $\begin{array}{l}\text { education professionals and peers } \\
\text { - Implementing e-module with two } \\
\text { students } \\
\text { - Revise the comment given by two } \\
\text { students } \\
\text { - Implementing e-module with fifteen } \\
\text { students } \\
\text { - Revise the comment given by fifteen } \\
\text { students } \\
\text { - Implementing e-module with twenty-nine } \\
\text { students } \\
\text { - Revise the comment given by twenty- } \\
\text { nine students } \\
\text { - Observe the affective, psychomotor, } \\
\text { process skills science ability using sheet } \\
\text { - Data student learning outcomes in the } \\
\text { form of a cognitive test of the ability to } \\
\text { think critically analysed using SPSS with } \\
\text { parametric test analysis of paired } \\
\text { samples. While the students' motivation is } \\
\text { derived from observation sheet during the } \\
\text { learning process was also tested by SPSS } \\
\text { with Mann-Whitney test analysis. }\end{array}$ \\
\hline Disseminate & $\begin{array}{l}\text { Deployment module into } \\
\text { SMA/MA in Surakarta }\end{array}$ & $\begin{array}{l}\text { The deployment phase is done to get } \\
\text { feedback, corrections, suggestions, ratings, } \\
\text { to enhance the development of the final } \\
\text { product to be ready for adoption by the } \\
\text { teachers SMA/MA in Surakarta. } \\
\text { Instruments used in this phase is a sheet } \\
\text { questionnaire and analyzed by descriptive a } \\
\text { qualitative. }\end{array}$ \\
\hline
\end{tabular}

\section{Results and Discussion}

Results of research and development, in the form of an electronic module Physics-based science process skills for improving critical thinking skills and student motivation. Assessment of learning is developed in accordance with the curriculum in 2013 at KD 5.1 to plan and carry out an experiment to investigate the relationship between force, mass, and acceleration in a straight motion. Data results from expert validation modules are presented in Figure 1. 


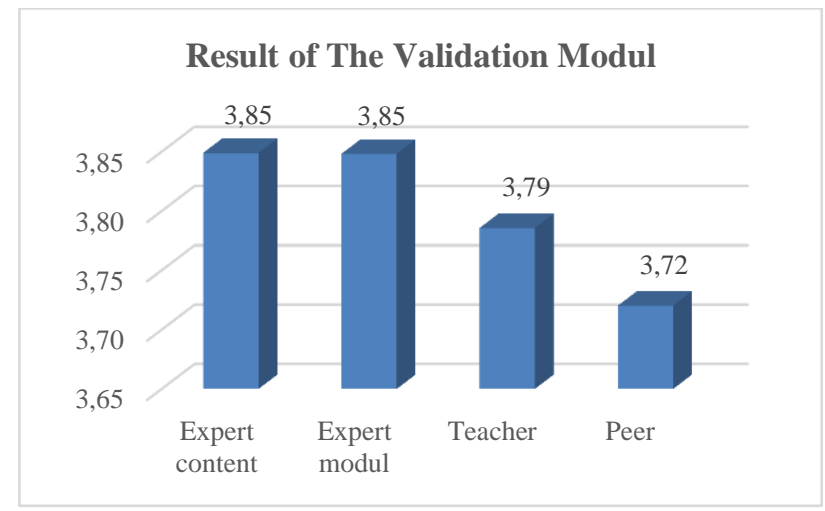

Figure 1. Result of The Validation Modules

Recap the results of the validation test as shown in Figure 1. The obtained an average module validation conducted by subject matter experts, media experts, education professionals (teachers) and colleagues. Validation is performed by a subject matter expert to get an average value of 3,85 that meet the criteria very well. The tests conducted by media experts to produce an average of 3,85 that meet the criteria very well. Validation results in practitioner education conducted at 2 Physics teacher produce an average of 3,78 that meet the criteria very well. Besides the validation conducted on two colleagues also generate an average of 3,72 that meet the criteria very well too. From some of the validation results, the average results of the validation of the overall validator 3,80 so it can be concluded that the module has met the criteria very well

Revision of the first products based on validation by experts and practitioners are obtained feedback or suggestions for improvement held before been tested on a small test. Results suggestions and input from experts and practitioners to use as improvements in materials, design modules and devices, then revisions and further product modules will be used on a small test.

Small test conducted by fifteen students. The results of the data obtained in the form of student responses to the module are presented in Table 2. Data from student responses on the small test, then be revised in accordance with the findings of the students while doing all the stages that exist within the module, improve sentences and sentence orders and directives in a module in practical activities. After the revision, the next big test carried out to implement the modules in learning.

Table 2. Student Response on Small Test

\begin{tabular}{|c|c|c|}
\hline No & Learning Activity & Response \\
\hline \multirow[t]{3}{*}{1} & The learning activities & There are still questions that confuse students \\
\hline & I & $\begin{array}{l}\text { 2. Addition of illustrations on the matter of evaluation } \\
\text { and discussion }\end{array}$ \\
\hline & & $\begin{array}{l}\text { 3. Students need to draw conclusions about the } \\
\text { direction }\end{array}$ \\
\hline \multirow[t]{3}{*}{2} & $\begin{array}{l}\text { The learning activities } \\
\text { II }\end{array}$ & $\begin{array}{l}\text { 1. On the identification form, the word "answer" } \\
\text { better replaced with "hypothesis", to be consistent with } \\
\text { previous orders }\end{array}$ \\
\hline & & 2. $\quad$ More briefed on lab activities \\
\hline & & The addition of illustrations in a matter of \\
\hline
\end{tabular}



discussion
3 The learning activities 1. There is a sentence that is less appropriate III command

2. Improvements in data analysis table

3. Addition of illustration in the example problems and discussion

After a small test, the next step is to do the big test. In the big test, the data obtained is the cognitive learning, learning outcomes affective, psychomotor learning outcomes, the results of science process skills, critical thinking skills result, students 'motivation and results of students' response to the module. Data from students' cognitive learning classes and class control samples are shown in Table 8 and Table 9.

Table 3. Description Data of Cognitive Learning Outcomes Student on Sample Class

\begin{tabular}{lccccc}
\hline Test & $\begin{array}{c}\text { The number of } \\
\text { student }\end{array}$ & Mean & $\begin{array}{c}\text { Std } \\
\text { Dev }\end{array}$ & Min & Maks \\
\hline Pretest & 29 & 35,7 & 9,588 & 15 & 60 \\
Posttest & 29 & 81,37 & 6,322 & 65 & 90 \\
\hline
\end{tabular}

Table 4. Description Data of Cognitive Learning Outcomes Student on Control Class

\begin{tabular}{lccccc}
\hline \multicolumn{1}{c}{ Test } & $\begin{array}{c}\text { The number of } \\
\text { student }\end{array}$ & Mean & $\begin{array}{c}\text { Std } \\
\text { Dev }\end{array}$ & Min & Maks \\
\hline Pretest & 28 & 36,61 & 9,335 & 15 & 55 \\
Posttest & 28 & 79,96 & 6,432 & 65 & 90 \\
\hline
\end{tabular}

Based on students cognitive learning outcome data shown in Table 3, it is known that the average cognitive achievement of students before applied learning module using 35,7 with a standard deviation of 9,58 and a minimum value obtained 15 , and the maximum value of 50 . The stocking of average obtained by a cognitive achievement of students after the implementation of learning use the module of 81,37 with a standard deviation of 6,32 and obtained a minimum of 65 and a maximum value of 90 . Based on students' cognitive learning outcome data shown in Table 4, it is known that the average cognitive achievement of students before being applied to the learning of 36,61 with a standard deviation of 9,335 and a minimum value obtained 15 , and the maximum value of 55. The average obtained by cognitive learning outcomes of students after learning activities amounted to 76,96 with a standard deviation of 6,432 and earned a minimum of 65 and a maximum value of 90 .

Based on the results of the pretest and posttest on a sample class and control class, it can then be used to determine the effectiveness of learning to use the application module with the formula $\mathrm{N}$-gain normalised. Results $\mathrm{N}$-gain normalised cognitive achievement of students gained an average of 0.68 . According to the criteria Hake (1998: 1) [11], a number of the achievements of these values indicates that the cognitive achievement of students categorised as "moderate".

Based on the summary of the analysis of the students' cognitive value, it is known that the normality of the data was tested using the Kolmogorov-Smirnov obtained significance level of 0,179 to 0,061 for the value pretest and posttest values. Both the 
value pretest-posttest greater than $\alpha=0,05$, so $\mathrm{H} 0$ is accepted and have a sense of the value pretest-posttest normal distribution. Based on the results of the homogeneity test with significance level of $0,908>0,05$, so $\mathrm{H} 0$ is accepted and the mean variation of each sample is the same (homogeneous).

The pretest-posttest data were normally distributed and homogeneous, so that further analysis will be done using one-way ANOVA test. Based on the calculation results obtained with probability $\mathrm{t}=-23,3520,000$ ( $\mathrm{p}$-value $<0,05$ ), so Ho rejected. The data show that there are significant differences between the cognitive learning value before it is applied to the value of learning module using cognitive learning outcomes after application of learning to use the module between the class and grade control samples. According to research conducted by Ince (2010) which states that there are significant differences in the value end of the test process skills between the experimental and control groups of students, for students to acquire skills such as research, discovery, scientific thinking. [12]. Affective student learning outcomes assessment during the learning process is done by using observation sheet ratings assessed by two observers. Based on data affective student learning outcomes assessment, it is known that the learning I average of affective learning outcomes of students by $87,81 \%$, amounting to 93,67 and learning activities II and III learning activities amounted to 94,48\%. From the data obtained by the observation that the affective learning outcomes of students always rise on each learning activity, with the category of "Very Good".

Assessment of students' critical thinking skills is done by using observation sheet were performed by two observers as well as the test and evaluation of the competency test as in student learning outcomes in the cognitive domain, the manufacture of critical thinking about referring to the critical thinking aspect of Facione. [4]. Data critical thinking skills obtained in the test phase of a large encompasses six aspects, among others focus on a question, ask and answer questions of clarification, observe and consider the results of observation, making induction and consider induction, evaluate the experiment, decide an action and interact with people other. Data critical thinking skills of students can be seen in Table 5 .

Tabel 5. The Result of Critical Thinking Ability Student

\begin{tabular}{lccccc}
\hline \multirow{2}{*}{ Observer } & \multicolumn{3}{c}{ Learning Activity } & \multirow{2}{*}{ Average $(\%$} & \multirow{2}{*}{ Categories } \\
\cline { 2 - 4 } & I & II & III & & \\
\hline Observer 1 & 83,57 & 87,02 & 89,17 & 86,59 & Very Good \\
Observer 2 & 79,04 & 86,42 & 88,45 & 84,64 & Very Good \\
\hline Rata-rata & 81,30 & 86,72 & 88,80 & 85,61 & Very Good \\
\hline
\end{tabular}

Based on Table 5, the average students critical thinking skills in learning activities 1 is 81,30 , at learning activities 2 is 86,72 and at learning activities 3 amounted to 88,80 . From the observations, it is known that on average the highest score to lowest score of critical thinking skills that focus on the question $(95,41 \%)$, observe and consider the results of observations $(92,08 \%)$, interacting with others $(91,25 \%)$, making induction and consider induction $(89,17 \%)$, ask and answer questions of classification $(88,75 \%)$, evaluating the trial $(82,5 \%)$, and the lowest score is deciding an action $(82,5 \%)$. From 
the results of these observations in mind that the module is very effective to stimulate students in designing a question in the learning process. Nonetheless, based on the results of observations for each meeting shows that the results of the students' critical thinking skills always increase which has a very good category.

There are two concepts that are discussed in the application of this module. Proving that the object in equilibrium has always maintained its initial state (stationary or moving at constant velocity). some students answered that the object will stop if the external force is released and the object may not retain the motion by himself. The answer may be a misconception in students. Whereas if the object in equilibrium $(\Sigma \mathrm{F}=$ 0 ) then the object in the initial state of silence, the object will remain stationary. If the object is in motion, then the motion will be continued at a steady pace.

In addition, students are also given the statement, if the net force acting on it is zero, then the object will move at a constant speed. some students answered If the net force acting on it is zero, then the object will experience a slowdown and if the net force acting on it is zero, then the object would be immediately stopped. but this is not the answer concept is expected. the actual concept is, if the net force acting on it is zero, then the object will move at a constant speed. Some of the answers can be misconceptions in students. To increase understanding of the concept of the dynamics of motion, then the learning is done by using this electronic module which directly serves phenomena in everyday life and do activities based on science process skills. This study also aims to improve students' critical thinking skills and student motivation.

The average of student motivation before learning of $73,86 \%$, while the average value of student motivation after learning to use the module by $94,68 \%$. From the analysis we found that almost all aspects of motivation to learn increases after learning by using electronic modules Physics-based learning science process skills.

Dissemination and implementation made to introduce product modules to school SMA / MA in Surakarta. Data dissemination and implementation in the form of comments, suggestions, and feedback from the teacher of Physics of the module and the module is expected Physics-based materials science process skills motion dynamics can be implemented as a new teaching materials. The results of the questionnaire stage of dissemination and implementation of products by five teachers of Physics in Surakarta shown in Table 14 gained an average of 3,93 for the content aspect of the module. For the aspects of the method of presentation, language, illustrations, completeness and physical aspects of 4,00. For aspects of it use 3,50. In this aspects of it use stage did not reach the value 4 because, according to the teacher still needs a clear allocation information about the stages of process skills that exist within the module. Based on these inputs, the teachers were given lesson plans used in applying the modules. Overall, the data dissemination and implementation phases of the product of the physics teachers have an average of 3,92 for all aspects considered very good.

\section{Conclusion}

1. Physical electronics module has been developed by integrating the science process skills for improving critical thinking skills and student motivation. Stages of science 
process skills that appear in the modules include observing, formulating the problem, formulating a hypothesis, identify variables, conduct experiments, analyze the data, summarize and communicate. All stages of the science process skills are included in each stage of learning. Critical thinking aspects contained in the module include: a focus on the question, observe and consider the results of observations, interact with others, make the induction and consider induction, ask and answer questions of classification, evaluate the experiment, and the lowest score is deciding an action. This electronic module is also used to increase students' motivation. Aspects of students' motivation contained within the modules are: do not get bored on routine tasks, showing interest, it is not easy to remove these beliefs, enjoy working independently, resilient in the face of adversity, be able to hold his, persevering in the face of the task, and happy looking and troubleshoot problems.

2. The modules are categorized either because it has been through several feasibility studies. Based on the feasibility test module has a decent category is used, which is supported by the results of calculations showed an average of 3,80 is greater than the minimum eligibility 3,78 . The results of the validation by subject matter experts on the feasibility of component content and feasibility of the language has a very good category with 3,85 . The results of the validation by media experts on the feasibility of components and presentation graph showed very good category with an average value of 3,84 . The results of the validation by the physics teacher showed very good category. The results of the validation by peer review showed very good category with an average value of 3,72. Module getting good response from the student category after using the module in the learning process. Results of student questionnaire responses which consists of four aspects produces very good category with the average percentage of 3,85 . Results disseminate conducted in five schools in the city of Surakarta produce modules with very good categories, with results from the average value of 3,92.

3. The results of the research and development of module-based Physics science process skills effectively improve students' critical thinking skills. Effectiveness module is based on the results of the calculation of the $\mathrm{N}$-gain in terms of the increase in cognitive test results and the critical thinking skills of students in grade samples of 0,67 and 0,59 in the control group were categorized as "moderate". The significance of the results obtained by paired t-test at $\mathrm{p}=0,000$, which means that there are significant differences between the values of the cognitive learning between classes and grade control samples. Based on these results it can be concluded that the module is a physics-based science process skills on the motion dynamics of matter effective in improving students' critical thinking skills.

4. Development of electronic modules Physics-based science process skills is considered an effective increase students' motivation. It can be seen from the increase in the average value increased motivation graders samples using electronic modules Physics-based science process skills, namely 94,68. The average value has increased rather than students' motivation to learn prior to the process of learning by using modules that the average value of 73,86 . Statistical analysis showed a significance value of 0,027 is lower than the significance level $\alpha=0,05$ so it can be concluded that 
students' motivation to use Physics module based science process skills better than conventional learning.

\section{References}

[1] Yudhi Munadi. 2010. Jakarta: Gaung Persada Pr

[2] Lewis, A., \& Smith, D. 1993. Theory into Practice, 32 (3), 131-137

[3] Paul, R. W., \& Elder, L. 2006. Journal of Developmental Education, 30 (2), 34 35.

[4] Facione, P. A. 2000. Informal Logic, 20 (1), 61-84

[5] Kennedy, M., Fisher, M. B., \& Ennis, R. H. 1991. Hillsdale, New Jersey: Lawrence Erlbaum \& Associates. (pp. 11-40).

[6] Pan, Guirong, et. al. 2010. Journal of Language Teaching and Research. Vol.1 (2), 151-156. ISSN. Page. 1798-4769.

[7] Sardiman. 2012. Jakarta: Rajawali Pers

[8] Thiagarajan, Sivasailam, DS, Semmel Melvyn. 1974. Minneapolis: Indian University.

[9] Suharsimi, Arikunto. 2010. Jakarta: PT. Rineke Cipta.

[10] Richard R.Hake. 1998. Journal od Physics Education Research, 66-67

[11] Ince, A.E., Guven, E., and Aydogdu, M. 2010. Journal of Turkish Science Education, vol. 7 (4). Hlm. 13-25.

[12] Elise D. Wallace. 2015. Journal of College Teaching\&Learning Vol.12-2 